\title{
Comparison of techniques for counting prokaryotes in marine planktonic and biofilm samples
}

\author{
Vanessa Ochi Agostini ${ }^{1,3,4,5}$, Letícia Terres Rodrigues ${ }^{2}$, Alexandre José Macedo ${ }^{3}$, Erik Muxagata ${ }^{1}$ \\ ${ }^{1}$ Laboratory of Zooplankton, Universidade Federal do Rio Grande (FURG), Institute of Oceanography (IO), \\ Av. Itália s/n km 8, campus Carreiros, CP 474, CEP 96203-900, Rio Grande, RS, Brazil. \\ (VOA) (Corresponding author). E-mail: voagostini@gmail.com. ORCID iD: https://orcid.org/0000-0002-8325-254X \\ (EM): E-mail: e.muxagata@gmail.com. ORCID iD: https://orcid.org/0000-0002-4210-5252 \\ ${ }^{2}$ Laboratory of Cell Culture, Universidade Federal do Rio Grande do Sul (UFRGS), Pharmacy Faculty, Av. Ipiranga 2752, \\ Bairro Azenha, CEP 90610-000, Porto Alegre, RS, Brazil. \\ (LTR) E-mail: letterres@ hotmail.com. ORCID iD: https://orcid.org/0000-0002-9402-0306 \\ ${ }^{3}$ Laboratory of Biofilms and Microbial Diversity, Universidade Federal do Rio Grande do Sul (UFRGS), \\ Pharmacy Faculty and Biotechnology Centre, Av. Ipiranga, 2752, Bairro Azenha, CEP 90610-000, Porto Alegre, RS, Brazil. \\ (AJM) E-mail: alexandre.macedo@ufrgs.br. ORCID iD: https://orcid.org/0000-0002-8951-4029 \\ ${ }^{4}$ Post-Graduate Programme on Biological Oceanography (PPGOB), \\ Scholarship of the Conselho Nacional de Desenvolvimento Científico e Tecnológico (CNPq). \\ ${ }^{5}$ Current address: Post-Doctoral fellow, Programa de Pós-Doutorado Empresarial do Conselho Nacional de \\ Desenvolvimento Científico e Tecnológico (PDI-CNPq), Regenera Moléculas do Mar, Brazil.
}

\begin{abstract}
Summary: Though a large number of techniques are available for the study of aquatic bacteria, the aim of this study was to establish a technique for analysing free-living and biofilm prokaryotic cells through laboratory assays. In particular, we wished to analyse the efficiency of ultrasound to detach and disrupt biofilm, to obtain an efficient stain treatment for quantifying free-living and biofilm prokaryotes in flow cytometry (FC), and to compare epifluorescence microscopy (EFM), scanning electron microscopy (SEM) and FC for quantifying free-living and biofilm prokaryotes\#. Marine-grade plywood substrates were immersed in natural marine water that was conditioned for 12 days. At 6 and 12 days, water aliquots and substrates were removed to estimate free-living and biofilm prokaryote density. Ultrasound efficiently removed marine biofilm from substrates (up to 94\%) without cell damage. FC analysis (unstained) reliably quantified marine plankton and young or mature biofilm prokaryotes compared with other staining (acridine orange, 4',6-diamidino-2-phenylindole, propidium iodide and green fluorescent nucleic acid), EFM or SEM techniques. FC and SEM achieved similar results, while a high variability was observed in the EFM technique. FC was faster and more precise than SEM because the count is not dependent on the observer.
\end{abstract}

Keywords: ecology; bacteria enumeration; flow cytometry; microbial methods; microscopy.

Comparación de técnicas para contar procariotas en muestras de biofilm y plancton marino

Resumen: A pesar de la gran cantidad de técnicas disponibles para el estudio de bacterias acuáticas, el objetivo de este estudio fue aplicar y proponer una técnica para el análisis de células procariotas de vida libre y asociado a biofilms en ensayos de laboratorio. En particular, deseamos analizar la eficiencia de de la aplicación de ultrasonidos para separar y romper el biofilm, obtener un tratamiento de tinción eficiente para cuantificar procariotas de vida libre y de biofilm por citometría de flujo (CF), y comparar microscopía de epifluorescencia (MEP), microscopía electrónica de barrido (MEB) y CF para cuantificar los procariotas de vida libre y de biofilm. Los sustratos de madera contrachapada de grado marino se sumergieron en agua marina natural que se acondicionó durante 12 días. A los 6 y 12 días, se retiraron alícuotas de agua y sustratos para estimar la densidad de procariotas de vida libre y asociados a los biofilms. Los ultrasonidos eliminaron de manera eficiente el biofilm marino de los sustratos (hasta 94\%) sin dañar las células. El análisis por CF (sin marcador) cuantificó de manera fiable las células del plancton marino y los procariotas de biofilms jóvenes o maduros en comparación con otras técnicas de marcación (naranja de acridina, 4', 6-diamidino-2-fenilindol, yoduro de propidio, ácido nucleico fluorescente verde), MEP o MEB. CF y MEB lograron resultados similares, mientras que se observó una alta variabilidad en la técnica EFM. Cuando se compara, $\mathrm{CF}$ es más rápido y más preciso que MED, ya que el recuento no depende del observador.

Palabras-clave: ecología; enumeración de bacteria; citometría de flujo; métodos microbianos; microscopía.

Citation/Como citar este artículo: Agostini V.O., Rodrigues L.T., Macedo A.J., Muxagata E. 2021. Comparison of techniques for counting prokaryotes in marine planktonic and biofilm samples. Sci. Mar. 85(3): 211-220. https://doi. org/10.3989/scimar.05117.019

Editor: M. Sala.

Received: August 20, 2020. Accepted: June 14, 2021. Published: August 24, 2021.

Copyright: $(\odot 2021$ CSIC. This is an open-access article distributed under the terms of the Creative Commons Attribution 4.0 International (CC BY 4.0) License. 


\section{INTRODUCTION}

Prokaryotes may be freely available in the water column as part of the plankton, interacting directly with chemical processes and playing a variety of roles in the food chain (e.g. the microbial loop), or they may even be attached to living (organisms) or non-living (debris) surfaces embedded in extracellular polymeric substances (EPS), forming microbial aggregates or biofilms, usually associated with matter and energy transport and biofouling (Kerstens et al. 2015, Bunse and Pinhassi 2017, Agostini et al. 2017). Free-living and biofilm prokaryotes have ecological and economic importance, so accurate determination of their abundance and biomass are important in most microbiology applications (Alsharif and Godfrey 2002).

Several methods have been proposed as alternatives for enumerating planktonic (free-living) and biofilm bacteria in natural aquatic environments and in laboratory assays (Boulos et al. 1999). Epifluorescence microscopy (EFM) is presently the most widely used microscopy technique (Muthukrishnan et al. 2017, Parthasarathy et al. 2018). The ability to accurately estimate bacterial abundance and standing stock biomass in fresh and marine waters by inspecting bacterioplankton cells stained with a fluorochrome has contributed to the field of aquatic microbial ecology (Suzuki 1993). The combined application of fluorescence staining and confocal laser scanning microscopy is useful for counting microbes in a biofilm sample, avoiding the loss of focus that is observed in traditional EFM for thick biofilm samples (Dang and Lovell 2002). The use of scanning electron microscopy (SEM) in this field relies on its ability to examine the dimensional topography and distribution of specific characteristics (Fischer et al. 2012) and reveals morphological structures of isolated organisms. However, microscopy techniques are time-consuming, requiring intrinsic preparation methods that can limit their use in routine analyses (Combs 2010, Beniac et al. 2015).

Since the 1990s, flow cytometry (FC) has been a rapid and accurate alternative to microscopic evaluation of free-living and biofilm bacteria in aquatic samples (Bouvier et al. 2011, Agostini et al. 2017). However, FC as well as some EFM techniques require pre-treatments to detach the individual bacterial cells from surfaces without rupturing cells. In the literature, one of the main procedures for removing bacterial biofilms from surfaces is ultrasound treatment (sonication) (Oliveira et al. 2006, Xu et al. 2012, Kerstens et al. 2015). However, this technique should be used with care, because ultrasound waves have the capacity to kill bacterial cells, depending on the frequency applied (Xu et al. 2012, Kerstens et al. 2015). Furthermore, the age of the biofilm could interfere in the composition and quantity of EPS and cell abundance (Flemming and Wingender 2010). In this case, ultrasound and staining could show different efficiency on young and mature biofilms.

According to Gasol and Giorgio (2000) and Ambriz-Aviña et al. (2014), bacteria can be analysed by FC when in suspension without fluorescent staining and be detected by light scatter alone or also by auto- fluorescence; however, staining would distinguish between cells and other particle-like debris (Davey and Kell 1996, 1997).

Acridine orange (AO) (3,6-acridinediamine) and DAPI (4'-6-diamidino-2-phenylidole, dihydrochloride) are the most widely used fluorochromes for bacterial staining (Zimmerman and Meyer-Reil 1974, Hobbie et al. 1977, Porter and Feig 1980). However, AO could also dye detritus and the EPS of biofilms and aggregates (Harrison et al. 2006). Propidium iodide (PI) contains a phenanthridinium ring and enhances the fluorescence of double-stranded nucleic acids, dyeing cells with compromised membranes (Shapiro and Nebe-Von-Caron 2004, Jin et al. 2005). However, the green fluorescent nucleic acid stain SYTO9 has been shown to mark non-compromised and compromised membrane cells of gram-positive and gram-negative prokaryotes. Thus, SYTO9 can enter all cells and is used for assessing total cell counts without dying detritus and EPS (Zhang et al. 2015, Berney et al. 2007, Mohammed et al. 2013). PI and SYTO9 together can be used in pure viability bacterial assays (see Supplementary Material Table S1).

Though a large number of techniques are available for studying natural aquatic planktonic and biofilm-associated bacteria, there is still no consensus on the most effective methodology for quantifying and characterizing these organisms rapidly, efficiently and economically, and no studies until now have presented a broader comparison of quantification of marine free-living and biofilm prokaryotes using EFM, SEM, and FC (unstained and with different stains) from laboratory assay samples. The aim of this study was to propose a protocol for analysing free-living and biofilm prokaryotes, ensuring efficiency and speed of analysis in laboratory assays. In particular, we aimed to analyse the efficiency of ultrasound for detaching and disrupting biofilm without compromising cells, to obtain an efficient stain treatment to quantify free-living and biofilm prokaryotes in FC, and to compare EFM, SEM and FC with different stains for quantifying free-living and biofilm prokaryotes of marine samples through laboratory assays.

\section{MATERIALS AND METHODS}

Natural marine water $(500 \mathrm{~mL})$ at $25 \mathrm{ppt}$ salinity was collected from Cassino Beach, Rio Grande, Brazil and incubated at $20^{\circ} \mathrm{C}$ for 12 days in a $12: 12$ (light:dark) photoperiod, under similar conditions to those at the collection site, with artificial white light (70 $\mu$ mol photons $\mathrm{s}^{-1} \mathrm{~m}^{-2}$ ) in a DBO incubator (Marconi $^{\circledR} 403$ ) in a Erlenmeyer flask (1 L). Marine-grade plywood substrates $\left(12 \mathrm{~cm}^{2}\right)$ commonly used in the naval field and considered a good surface for biofilm development (Golladay and Sinsabaugh 1991, Sailer et al. 2010, Agostini et al. 2016) were deposited in cultures to allow biofilm growth. The culture medium was shaken manually four times per day (every 6 hours) (Agostini et al. 2016) and at the sixth and twelfth day of exposure, aliquots $(1 \mathrm{~mL})$ of the culture medium and/or substrates were removed for evaluation of the 
planktonic and biofilm bacteria, respectively. These times were chosen because a preliminary laboratory experiment showed us that they would be sufficient to allow biofilm growth with a high number of cells. At approximately 10 days, the biofilm is mature, the matrix disrupts and cell dispersion occurs.

Aliquots with planktonic samples were immediately placed in microtubes $\left(2 \mathrm{~mL}\right.$, Eppendorf Gene $\left.{ }^{\odot}\right)$, while the substrates were individually placed in $50 \mathrm{~mL}$ sterile saline solution to detach the biofilm using three pulses of 15 seconds $(20 \mathrm{kHz})$ on each side of the substrate using a Cole-Parmer ${ }^{\circledR}$ ultrasound (series 4710) (Oliveira et al. 2006), with the exception of the substrates submitted to evaluation under SEM. After detachment, $1 \mathrm{~mL}$ of the biological suspension was placed in a reaction tube. The samples were fixed with $4 \%$ sterile formaldehyde for EFM and FC analysis and with $1 \%$ sterile glutaraldehyde for SEM analysis (Fig. 1). In this way, we performed the assays with dead cells with a damaged membrane caused by the use of formaldehyde fixative (Crawford and Barer 1951). The estimation of the number of prokaryotes will be presented as cells per $\mathrm{mL}$ (cells $\mathrm{ml}^{-1}$ ) and cells per $\mathrm{cm}^{2}$ (cells $\mathrm{cm}^{-2}$ ) for free-living and biofilm organisms, respectively.

\section{Ultrasound biofilm detachment and bacteria cell damage evaluation}

The substrates with intact biofilm were analysed using a JEOL JSM-6060 scanning electron microscope (SEM), representing the biofilm before the ultrasound procedure, and subjected to biofilm detachment following the methodology of Oliveira et al. (2006), representing the biofilm after the ultrasound procedure in triplicates. After being fixed with $1 \%$ sterile glutaraldehyde for 12 hours, which does not cause cell membrane damage (McKenzie 2019), the substrates were dehydrat- ed with increasing concentrations of ethanol $(50,70,80$, 95 and $100 \%$ ) (20 min each), dried by the addition of one drop of $100 \%$ acetone and fixed on aluminium stubs covered with gold (Freitas et al. 2010). To calculate the biofilm prokaryote density before and after the ultrasound procedure, the prokaryotes present on the substrates were counted from ten photographic images per substrate using a $11000 \times$ magnification $\left(97 \mu \mathrm{m}^{2}\right.$ of area) and the biofilm prokaryote (BP) density (cells $\mathrm{cm}^{-2}$ ) was estimated by applying the following formula:

$$
\mathrm{BP}=\frac{\text { CountM } * \mathrm{U}}{\mathrm{PA}}
$$

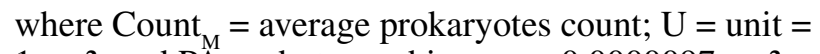
$1 \mathrm{~cm}^{2}$; and $\mathrm{PA}=$ photographic area $=0.0000097 \mathrm{~cm}^{2}$.

Bacteria cell damage (a compromised membrane) was also evaluated after ultrasound procedures in triplicates. The same methodology as that applied for SEM (described above) was used; however, the material detached from the substrates after the ultrasound procedure was filtered on polycarbonate filters of 0.2 $\mu \mathrm{m}$ (Whatman $\varnothing 25 \mathrm{~mm}$ ). The material was not fixed to avoid interference in the cell membrane, and the substrates and filters were oven-dried $\left(40^{\circ} \mathrm{C}\right)$ for $24 \mathrm{~h}$ and directly analysed under SEM.

To calculate the percentage of compromised bacterial membranes, the proportion of prokaryotes with intact and compromised membranes (see Fig. S1) present on the substrates and filters was determined from ten photographic images per replicate at $10000 \times$ magnification $\left(107 \mu \mathrm{m}^{2}\right.$ of area).

\section{Flow cytometry}

Biological material present on the samples previously fixed with $4 \%$ formaldehyde was stained with

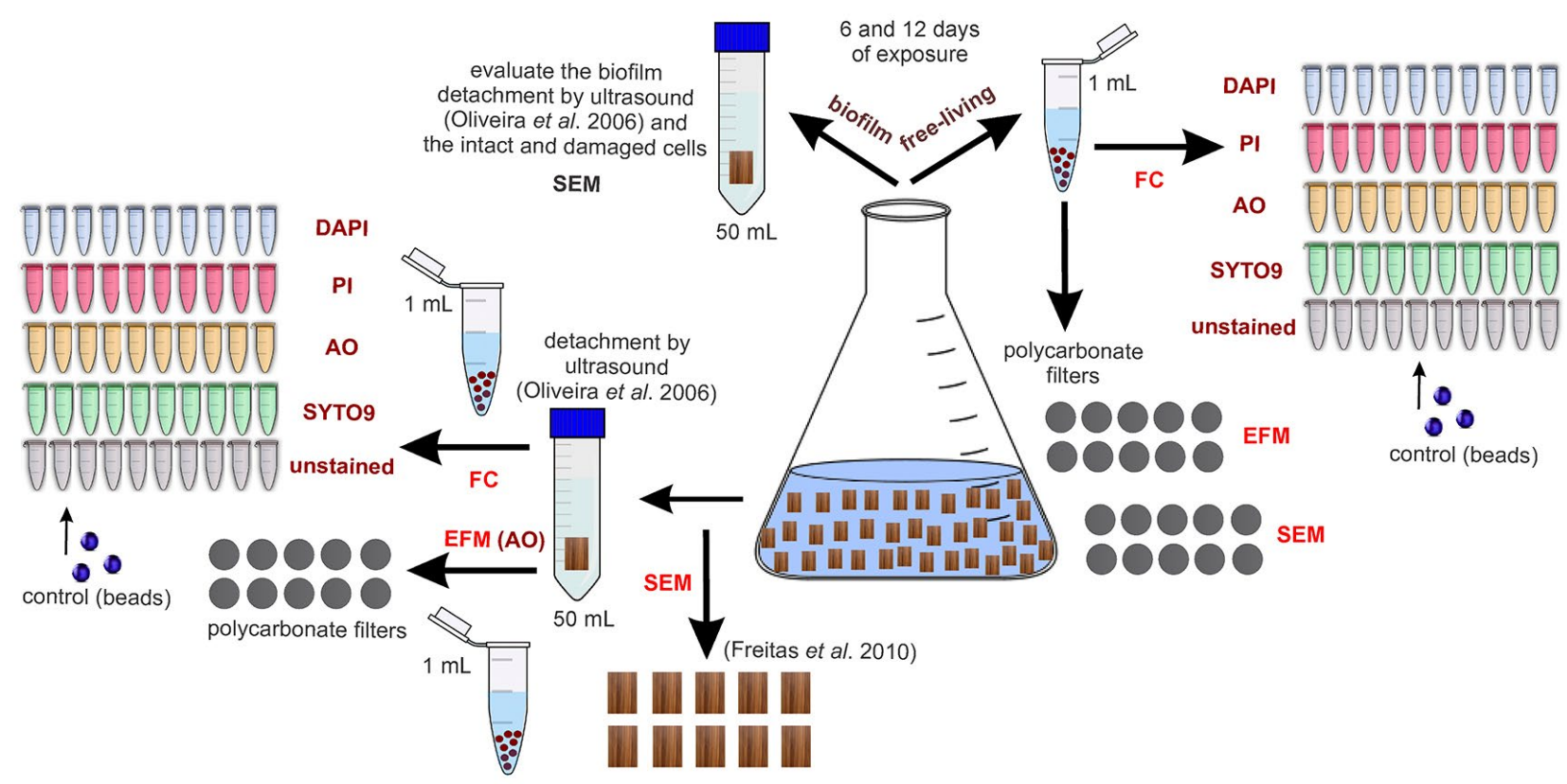

Fig. 1. - Experimental design used to define the best flow cytometer (FC) protocol for counting and measuring planktonic and biofilm marine prokaryotes compared with epifluorescence microscopy (EFM) and scanning electron microscopy (SEM). 
AO $\left(\right.$ Merck $\left.^{\mathrm{TM}}\right)$ and DAPI (Sigma-Aldrich ${ }^{\mathrm{TM}}$ ) following the protocol of Kepner and Pratt (1994). To stain prokaryotes with AO or DAPI, $100 \mu \mathrm{L}$ of an aqueous stock solution of AO $\left(1 \mathrm{~g} \mathrm{~L}^{-1}\right)$ or DAPI $\left(0.01 \mathrm{~g} \mathrm{~L}^{-1}\right)$ was added per $\mathrm{mL}$ of sample (attaining a final concentration of $100 \mu \mathrm{g} \mathrm{mL} \mathrm{m}^{-1}$ for $\mathrm{AO}$ and $1 \mu \mathrm{g} \mathrm{ml} \mathrm{m}^{-1}$ for DAPI), and the resulting solution was incubated for 15 minutes at room temperature in the dark (Porter and Feig 1980).

PI (20 mM solution in DMSO) and green fluorescent nucleic acid (SYTO9) $(3.34 \mathrm{mM}$ solution in DMSO - Molecular Probes ${ }^{\mathrm{TM}}$ ) were added in the ratio of $1.5 \mu \mathrm{L}$ of dye for $998.5 \mu \mathrm{L}$ of biological suspension. The samples were incubated at room temperature in the dark for 15 minutes (Shapiro and Nebe-Von-Caron 2004, Ophus 2014) (see Table S2).

Free-living (cells $\mathrm{mL}^{-1}$ ) and biofilm (cells $\mathrm{cm}^{-2}$ ) prokaryotic density was estimated using a calibrated flow cytometer (BD FACSVerse ${ }^{\mathrm{TM}}$ ) equipped with one air-cooled blue laser at $488 \mathrm{~nm}$ from ten replicates using the BD FACSuite ${ }^{\mathrm{TM}}$ software for analysis. The flow cytometer was calibrated by performing several pilot experiments using various samples. Samples were run at rates below 1000 events per second and a time-acquisition of 60 seconds per sample was used as a fixed acquisition time. The prokaryote population of the FC plot was presented on a logarithmic scale.

The flow cytometer's performance was calibrated with Control Cytometer Setup and Tracking. To detect the multiple marine microbial diversity (populations with different characteristics such as complexity, size and structure), no gate was used in the forward scatter (FSC) vs side scatter (SSC) parameters, so all events were considered during the FC analysis. This procedure was conducted to avoid the miscounting of any bacteria present on the sample. The threshold level was set at 10000 on the FSC parameter and at 200 for the following parameters: SSC, FL-1 (FITC) and PE (FL-3).

The SYTO9 dye was used in the FL-1 channel (527/32 nm). The PI, AO and DAPI staining were detected at red fluorescence in the FL-3 channel (586/42 $\mathrm{nm})$. An unstained sample was used as a negative background and only the events with higher fluorescence intensity than the unstained ones were considered positive for the SYTO9, DAPI, AO and PI analysis.

\section{Epifluorescence microscopy}

The biological suspension present on water samples and plywood substrates was filtered on polycarbonate filters of $0.2 \mu \mathrm{m}$ (Whatman $\varnothing 25 \mathrm{~mm}$ ) darkened (for 20 min) with Irgalan Black, stained with AO (1\%), and viewed under EFM with phase contrast (Zeiss Axioplan) at $1000 \times$ magnification (fitted with an $\mathrm{Hg}$ 50-W lamp, a BP 450 to $490 \mathrm{~nm}$ excitation filter, and an LP $515 \mathrm{~nm}$ emission filter).

To estimate the free-living (cells $\mathrm{mL}^{-1}$ ) and biofilm (cells $\mathrm{cm}^{-2}$ ) prokaryote density, all prokaryotes present in a grid of $100 \mu \mathrm{m}^{2}(1000 \times$ magnification) were counted (2122 cells in total) from ten replicates (five grids per replicate), applying the following formulas:
Free-living prokaryotes

$$
\mathrm{FLP}=\frac{\text { CountM } * \mathrm{FA}}{\mathrm{GA} * \mathrm{VF}}
$$

where Count $_{\mathrm{M}}=$ average prokaryotes count; $\mathrm{FA}=$ filter area $=3.46 \mathrm{~cm}^{2} ; \mathrm{GA}=$ grid area $=0.00001 \mathrm{~cm}^{2}$; and $\mathrm{VF}$ $=$ volume filtered $=1 \mathrm{~mL}$.

Biofilm prokaryotes

$$
\mathrm{BP}=\frac{\text { CountM } * \mathrm{FA} * \mathrm{DV}}{\mathrm{GA} * \mathrm{VF} * \mathrm{SA}}
$$

Where Count $_{\mathrm{M}}=$ average prokaryotes count; $\mathrm{FA}=$ filter area $=3.46 \mathrm{~cm}^{2} ; \mathrm{GA}=$ grid area $=0.00001 \mathrm{~cm}^{2} ; \mathrm{VF}=$ volume filtered $=1 \mathrm{~mL} ; \mathrm{DV}=$ dilution volume $=50$ $\mathrm{mL} ;$ and $\mathrm{SA}=$ substrate area $=25 \mathrm{~cm}^{2}$

\section{Scanning electron microscopy}

The planktonic prokaryote samples followed the same filtration procedure as that detailed above on polycarbonate filters, while for biofilm prokaryotes, the plywood substrates were directly analysed under SEM. The SEM sample procedures followed Freitas et al. (2010).

To estimate free-living (cells $\mathrm{mL}^{-1}$ ) and biofilm (cells $\mathrm{cm}^{-2}$ ) prokaryote density, respectively, in polycarbonate filters and plywood substrates, all prokaryotes present in an area of $97 \mu^{2}(11000 \times$ magnification) were counted (552 cells in total) from ten replicates (five areas per replicate), applying the following formulas:

Free-living prokaryotes

$$
\mathrm{FLP}=\frac{\text { CountM } * \mathrm{FA}}{\mathrm{PA} * \mathrm{VF}}
$$

where Count $_{\mathrm{M}}=$ average prokaryotes count $\mathrm{FA}=$ filter area $=3.46 \mathrm{~cm}^{2} ; \mathrm{PA}=$ photo area $=0.0000097 \mathrm{~cm}^{2}$; and $\mathrm{VF}=$ Volume filtered $=1 \mathrm{~mL}$.

\section{Biofilm prokaryotes}

$$
\mathrm{BP}=\frac{\text { CountM } * \mathrm{U}}{\mathrm{PA}}
$$

where Count $_{\mathrm{M}}=$ average prokaryotes count; $\mathrm{U}=$ unit $=$ $1 \mathrm{~cm}^{2} ; \mathrm{PA}=$ photo area $=0.0000097 \mathrm{~cm}^{2}$.

\section{Statistical analysis}

General linear model (GLM) analysis was applied to Poisson data distribution with a "log" link function to evaluate differences in prokaryote density before and after the ultrasound procedure and between the FC, EFM and SEM methodologies for each exposure time. A one-way ANOVA was used to detect significant differences between treatments for data with a normal distribution. To compare prokaryote stain percentages among different stain-treatments using the free software R 3.4.1 (2017), post-hoc Tukey tests followed the analyses ( $p>0.05$ means no statistical difference). 
A

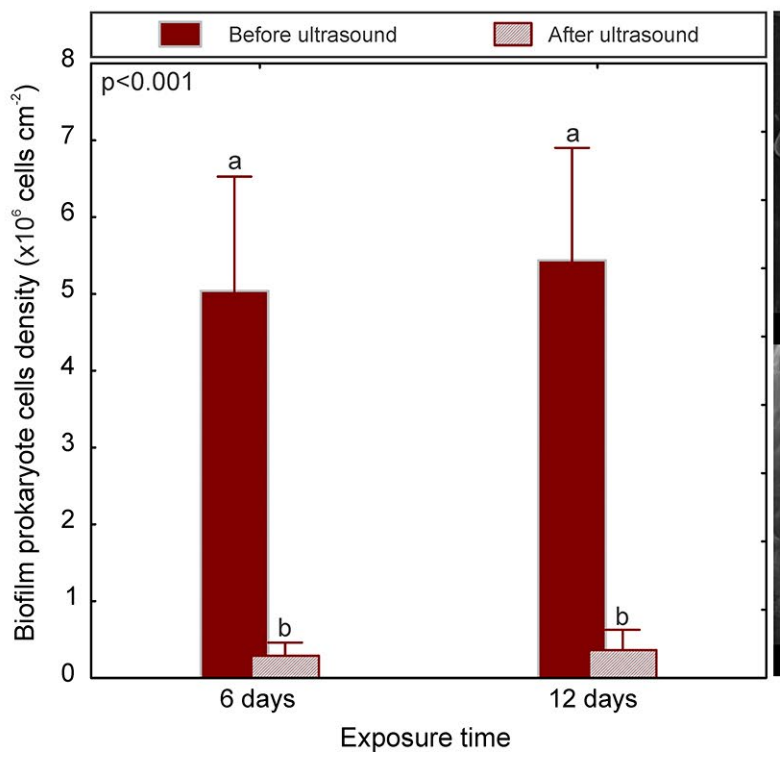

B

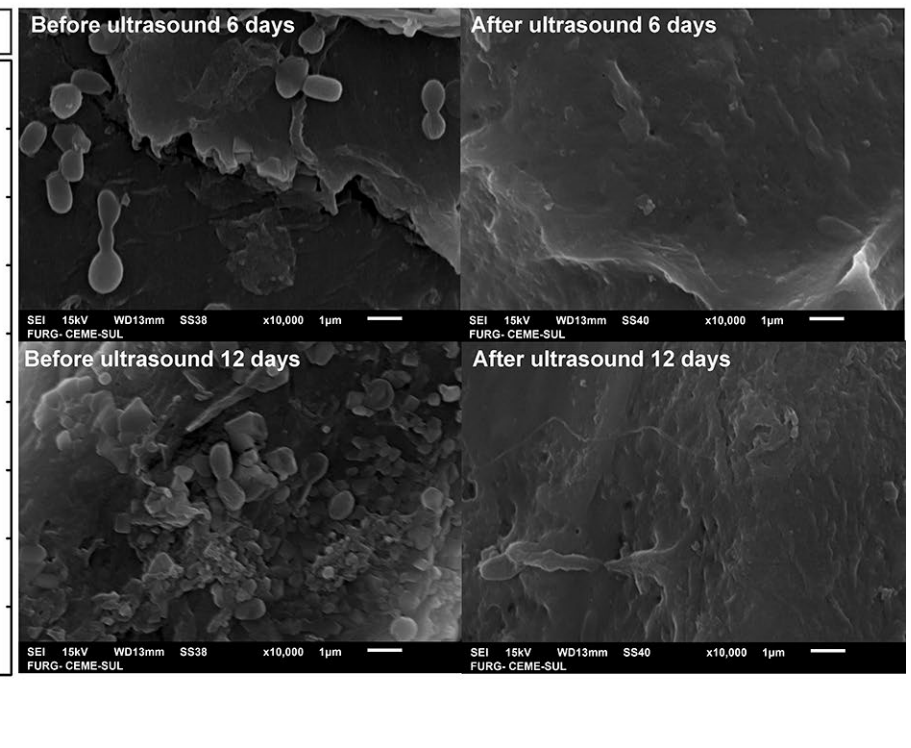

Fig. 2. - A: GLM results showing differences in biofilm prokaryote density (cells $\mathrm{cm}^{-2}$ ) before and after the ultrasound procedure at 6 and 12 days of exposure. The vertical lines denote confidence intervals (95\%) (standard error*1.96). B: Scanning electron microscopy pictures show differences in the prokaryote density on marine-grade plywood surface at 6 and 12 days of exposure before and after the ultrasound procedure. Lowercase letters indicate similarities $(p>0.05)$ or statistical differences $(p<0.05)$ in prokaryote cell quantification between stains, and capital letters indicate statistical similarities $(p>0.05)$ or differences $(p<0.05)$ in detritus quantification between stains.

\section{RESULTS}

The ultrasound procedure removed $94 \%$ and $93 \%$ of biofilm bacterial density the from plywood substrates at $6(p<0.001)$ and 12 days $(p<0.001)$ of age, respectively (Fig. 2A). Before the ultrasound procedure, the biofilm bacterial density on the substrate was $5.1 \times 10^{6}$ and $5.6 \times 10^{6}$ cells cm$~^{-2}$ at 6 and 12 days, respectively. After the ultrasound procedure, it was $0.2 \times 10^{6}$ cells cm $\mathrm{cm}^{-2}$ and $0.3 \times 10^{6}$ cells $\mathrm{cm}^{-2}$ at 6 and 12 days, respectively. The SEM images also show the biofilm community before and after the ultrasound procedure at different biofilm ages (Fig. 2B). The cell integrity after the ultrasound procedure was retained after 6 and 12 days of exposure $(\mathrm{p}=0.828)$. The percentage of compromised cell membrane was similar $(\mathrm{p}=0.608)$ between $6(2.7 \%)$ and $12(2.8 \%)$ days of exposure and before (2.6\%) and after $(2.8 \%)$ the ultrasound procedure $(\mathrm{p}=0.692)$.

The bacterial count by FC using different stains was determined by comparisons between prokaryote cell bars in a single community and time, as well as by comparisons of each stain treatment between free-living and biofilm communities at 6 and 12 days. It was observed that for free-living bacteria at $6\left(\mathrm{~F}_{(4,45)}=0.041 ; \mathrm{p}=0.997\right)$ (see Fig. $\left.\mathrm{S} 2 \mathrm{~A}\right)$ or 12 days of exposure $\left(\mathrm{F}_{(4,45)}=0.009 ; \mathrm{p}=1.000\right)$ (see Fig. S2B), the treatments showed no significant differences. However, for the biofilm-associated bacteria, a higher number of non-stained particles was found in the PI $(6.63 \%)$ than in the unstained $(0.00 \%)$, AO $(1.02 \%)$ and SYTO9 $(0.26 \%)$ treatments at 6 days $\left(F_{(4,45)}=5.675 ; p<0.009\right)$ (see Fig. S2C); and a higher number of non-stained particles was found in the PI treatment $(10.64 \%)$ than in the unstained $(0.00 \%)$, AO (1.04\%), DAPI (1.02\%) and SYTO9 $(0.56 \%)$ treatments at 12 days $\left(\mathrm{F}_{(4,45)}=4.798 ; \mathrm{p}<0.02\right)$ (see Figs S2D, S3). We used the percentage of stained and non-stained cells to reveal the efficiency of the different stains, but we also provided the bacterial cell count in the electronic supplementary material (see prokaryotes cell count values in Table S3).

Similar average percentages of non-stained particles were observed between free-living and biofilm samples $(\sim 2.40 \%)$ and between 6 and 12 days $(\sim 2.40 \%)$. However, when we evaluated just the SYTO9 treatment, we observed that the planktonic samples $(1.88 \%)$ showed more non-stained particles than the biofilm samples $(0.41 \%)\left(\mathrm{F}_{(1,36)}=65.662\right.$; $\mathrm{p}<0.001)$ and the number of these particles increased from $6(0.80 \%)$ to 12 days $(1.49 \%)$ of experiment (see Fig. S2C, D) $\left(F_{(1,36)}=14.330 ; p<0.001\right)$.

When the FC (unstained) and microscopy (EFM and SEM) techniques for estimating bacterial density were compared, similar results were obtained for free-living ( $\mathrm{p}=0.094$ at 6 days of exposure) (see Fig. 3A) and biofilm-associated bacteria $(p=0.058$ at 6 and $\mathrm{p}=0.051$ at 12 days of age) (Fig. 3C, D). However, at 12 days of exposure, free-living prokaryote density in EFM was higher than in FC $(\mathrm{p}<0.001)$, although similar to SEM ( $\mathrm{p}=0.316$ ) (Fig. 3B). Statistically, EFM only showed higher average bacterial density free-living cells at 12 days than FC and SEM. In the other observations, no statistically significant differences were observed between EFM and FC and SEM due to high variability in the EFM results (Fig. 3; see photos in Fig. S4). 


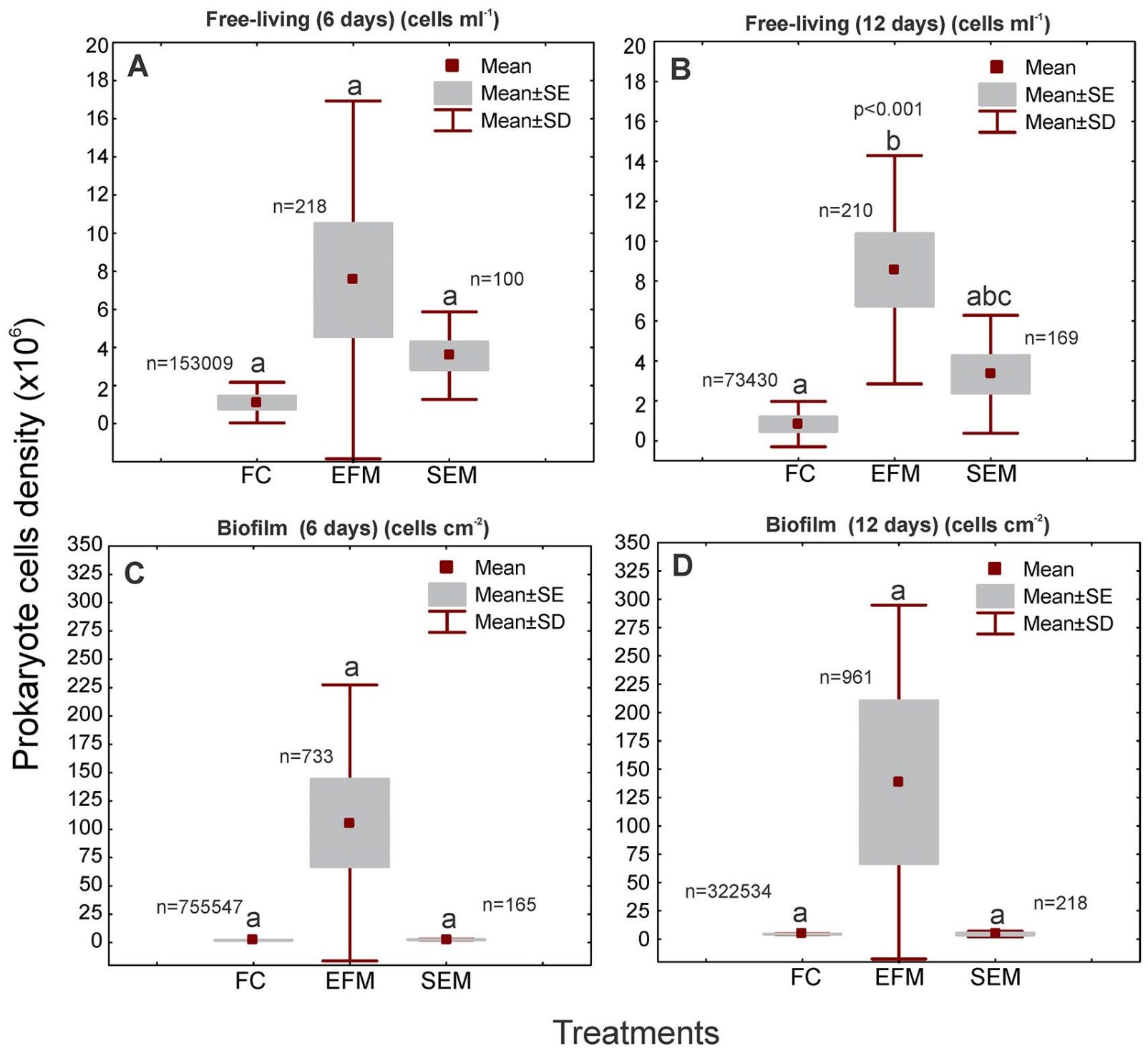

Fig. 3. - GLM results showing differences in free-living $\left(\right.$ cells $\left.\mathrm{ml}^{-1}\right)$ and biofilm (cells $\left.\mathrm{cm}^{-2}\right)$ prokaryote density between flow cytometer (FCunstained), epifluorescence microscopy (EFM-AO stain) and scanning electron microscopy (SEM). A, free-living prokaryotes at 6 days; B, free-living prokaryotes at 12 days; $\mathrm{C}$, biofilm prokaryotes at 6 days; $\mathrm{D}$, biofilm prokaryotes at 12 days. Lowercase letters indicate statistical similarities $(\mathrm{p}>0.05)$ or differences $(\mathrm{p}<0.05)$.

\section{DISCUSSION}

The efficiency of the ultrasound procedure for detaching prokaryote cells from steel, glass, ceramic and plastic surfaces has been reported (Xu et al. 2012, Sgier et al. 2016), but not from plywood, which shows a more heterogeneous surface. Moreover, cell damage has not been evaluated. The results obtained may be associated with the ultrasound frequency applied $(20 \mathrm{kHz})$, which was within the frequency range $(18-55 \mathrm{kHz})$ suggested by other researchers (Oulahal et al. 2004, Oliveira et al. 2006, Sgier et al. 2016), ensuring effective removal of young (6 days) and mature (12 days) biofilm from surfaces, EPS disruption and prokaryote cell integrity when the samples are fixed with glutaraldehyde. Thus, the ultrasound procedure is excellent for removing marine biofilm prokaryotes from hard substrates.

In this study, we followed different protocols for the SEM and FC-EFM analysis. For SEM, the fixative ap- plied was glutaraldehyde $1 \%$, while for FC and EFM it was formaldehyde $4 \%$. This use of different fixatives resulted in different cell membrane integrity. According to Crawford and Barer (1951) and McKenzie (2019), formaldehyde causes cell damage while glutaraldehyde does not, justifying the use of PI stain for FC and the evaluation of cell integrity with SEM photos.

Similar biofilm bacterial density was observed between 6 and 12 days of exposure (see Fig. 1), which could be a result of the biofilm dispersion that occurs in mature biofilms after they have reached the support capacity of the system (Flemming and Wingender 2010). Hence, different exposure times could result in similar bacterial densities, a pattern which has also been observed in free-living cells (Agostini et al. 2016, Kim and Lee 2016).

After detachment and disruption of the marine biofilm, the biological suspension can be tested by FC to evaluate specific characteristics such as number of bacteria, complexity, size and viability at the cellular level (Shapiro 
and Nebe-Von-Caron 2004, Bouvier et al. 2011). In this study, the efficiency of different stains was also tested. The unstained treatment showed the best cost-benefit for estimating bacterial densities on biofilm (cells $\mathrm{cm}^{-2}$ ) and free-living (cells $\mathrm{mL}^{-1}$ ) bacterial suspensions for all exposures/ages when compared with the results obtained with the SYTO9, PI, DAPI, AO stains when the samples are obtained from laboratory assays. Unstained samples can be applied in FC analysis without compromising the study (Gant et al. 1993, Walberg et al. 1996, Ambriz-Aviña et al. 2014), because non-prokaryote particles (eukaryotes + detritus) were always a small proportion $(<3 \%)$ of the planktonic and biofilm samples, as observed in other studies (Agostini et al. 2018a,b, Lopes et al. 2018).

While DAPI only stains living organisms, AO stains organisms and non-living particles such as EPS and detritus (Kepner and Pratt 1994, Harrison et al. 2006). Colloids may also be stained by these agents and be autofluorescent (Porter and Feig 1980, Harrison et al. 2006); hence, the abundance estimates were similar to those without staining. This finding is consistent with those of Suzuki (1993) and Posch et al. (2001), who observed 70\% and $90 \%$ lower bacterial numbers, respectively, on staining with DAPI compared with staining with AO by EFM. These results could be associated with AO's overestimation of detritus count.

Statistical differences were observed in the biofilm community between the PI stain and the other treatments. PI cannot traverse intact cell membranes, so only cells with compromised membranes can be counted (Shapiro and Nebe-Von-Caron 2004, Jin et al. 2005). This relationship was significant only for the biofilm samples, a finding which could be associated with EPS presence (Flemming and Wingender 2010), allowing more cells to remain with intact membranes even after the fixation process (death). For this reason, PI has been commonly used to label dead cells (Jin et al. 2005, Falcioni et al. 2008, Franklin et al. 2011), although fast-growing cells can also show ruptured membranes, allowing PI marking (Shi et al. 2007).

SYTO9 is an excellent stain to apply in studies concerning bacterial community and can be applied with other stains to differentiate bacterial populations (Berney et al. 2007, Mohammed et al. 2013, Zhang et al. 2015). Analyses of unstained samples by FC is less expensive (on consumables) than that of samples treated with SYTO9 (2.00 USD per sample in this study) and statistically showed the same results.

Comparison of marine prokaryote densities between FC (unstained), EFM and SEM in the current work showed that FC can also be applied to estimate marine free-living and biofilm prokaryotes. FC can also be applied to estimate natural marine free-living (Gasol and Giorgio 2000) and biofilm prokaryotes (Amalfitano and Fazi 2008), as observed for bacterioplankton from lakes (Felip et al. 2007). FC has also been successfully applied to estimate total free-living bacteria in drinking water (Yu et al. 2015) and in marine biofilm density on microplastics (Sgier et al. 2016). Jochem (2001) evaluated the total density of marine planktonic heterotrophic bacteria by EFM and FC and observed equivalent estimates between the two methodologies. Total bacterioplankton density estimates by FC were compared with counts by direct ob- servation using EFM, showing that the results of the FC could be considered reliable (Monfort and Baleux 1992). Unlike the aforementioned studies, the data of the present study provide a broader comparison of quantification of marine free-living and biofilm prokaryotes by EFM SEM, and FC (with different stains and unstained).

Though there were no significant differences between the three methodologies (see Fig. 3), we observed different mean densities of prokaryotes between treatments, with EFM having a higher density than SEM and FC for all samples analysed. These results may vary with the observer performing the counting, which may lead to higher counting error in low magnification $(1000 \times)$ than in SEM and FC, leading to overestimation of the number of bacteria. Epifluorescence microscope techniques are time-consuming and require considerable effort to obtain precise and accurate results (Cos et al. 2010, Bouvier et al. 2011). For the planktonic community, FC also showed a lower prokaryote number than SEM, indicating an underestimation, as observed by Felip et al. (2007), who related these results to the presence of small cells $\left(<0.06 \mu \mathrm{m}^{3}\right)$.

In the present study, based on the differences in microscopy magnification between EFM and SEM, different cell numbers were counted per replicate, and a four-fold increase in prokaryotes was observed by EFM analysis; however, the lower magnification $(1000 \times)$ used in EFM than in SEM $(11000 \times)$ could lead to an overestimation. Garren and Azam (2010) observed that SEM bacterial abundance estimations can be ten times lower than fluorescence-based techniques, but these authors considered that the SEM method underestimated prokaryote densities, contrasting with the results of the present work. SEM can be an alternative to fluorescence techniques, such as EFM, because it has the advantage of acquiring images at higher resolution, distinguishing between detritus and prokaryote and eukaryote cells (Garren and Azam 2010). However, sample preparation is costly and more time is required to analyse the samples and images.

FC, which requires less sample processing, thus appears to be a more efficient technique for obtaining rapid and accurate estimations of bacterioplankton densities than EFM, which requires a greater extent of sample processing (Troussellier et al. 1999). According to Jochem (2001), Gasol and Giorgio (2000) and Kerstens et al. (2015), FC is a rapid, accurate and promising technique for environmental free-living and biofilm prokaryote quantification, providing new information about the structure and functioning of prokaryotic communities. However, the use of FC requires single-cell suspensions (Nebevon-Caron et al. 1999, 2000, Kerstens et al. 2015), which can be obtained after the ultrasound procedure proposed by Oliveira et al. (2006) and were tested in the present study. Microscopy analyses lack precision because the number of cells examined is lower compared than that obtained by FC (Gasol and Giorgio 2000).

In this study, ultrasound treatment ensured removal of more than $93 \%$ of the young and mature marine biofilm from the plywood substrates. Moreover, it disrupted the EPS without compromising the cells. High variability was observed in the EFM technique, so no conclusive results could be achieved from the EFM analysis. FC and SEM achieved similar results, $\mathrm{FC}$ but is faster, more precise and 
cheaper (sample preparation) than SEM. Unstained samples showed similar results to those of stained samples. In particular, the FC detection of unstained samples was likely biased by the lack of suspended particulate matter (debris) in the laboratory samples. This application for natural samples should be investigated with different biofilm growing settings. In other words, though FC detection of unstained samples showed comparable results to those of stained samples and to the SEM technique, it must be emphasized that the use of FC with unstained samples is a valid method as long as the samples have low amounts of debris; otherwise, it would be necessary to stain the samples for a reliable cell count.

\section{ACKNOWLEDGEMENTS}

The authors acknowledge the support of the Universidade Federal of Rio Grande (FURG) and the Conselho Nacional de Desenvolvimento Científico e Tecnológico (CNPq-141217/2014-6). We also wish to thank the Faculdade de Fármacia of the Universidade Federal do Rio Grande (UFRGS) for the flow cytometer (BDFacsVer$\mathrm{se}^{\mathrm{TM}}$ ), the Laboratório de Fitoplâncton e Microorganismos Marinhos for the epifluorescence analyses and the Centro de Microscopia Eletrônica da Zona Sul (CEME-SUL) of FURG for the scanning electron microscopy analyses.

\section{FUNDING}

This work was supported by the grants PRONEM FAPERGS/CNPq 11/2014 (6/2551-000244-4).

\section{CONFLICT OF INTEREST}

No conflict of interest is declared.

\section{AUTHOR CONTRIBUTION STATEMENTS}

All authors agree with the publication of this material.

All authors have materially participated in the research and/or article preparation from experimental design to writing.

\section{REFERENCES}

Agostini V.O., Macedo A.J., Muxagata E.M. 2016. Evaluation of antibiotics as a methodological procedure to inhibit free-living and biofilm bacteria in marine zooplankton culture. An. Acad. Bras. Cienc. 88: 733-746. https://doi.org/10.1590/0001-3765201620150454

Agostini V.O., Ritter M.N., Macedo A.J., et al. 2017. What determines sclerobiont colonization on marine mollusk shells? PLOS ONE 12: e0184745. https://doi.org/10.1371/journal.pone.0184745

Agostini V.O., Macedo A.J., Muxagata E.M. 2018a. Inhibition of biofilm bacteria and adherent fungi from marine plankton cultures using an antimicrobial combination. Inter. Aquatic. Res. 10: 165-177. https://doi.org/10.1007/s40071-018-0198-1

Agostini V.O., Macedo A.J., Muxagata E.M. 2018b. Effect of antimicrobials, salinity, and contamination by air on bacterial and fungal growth in cyprid cultures of Amphibalanus improvisus. Mar. Ecol. 39: e12523. https://doi.org/10.1111/maec.12523

Alsharif R., Godfrey W. 2002. Bacterial Detection and Live/Dead Discrimination by Flow Cytometry. BD Biosciences, San Jose, CA, 6 pp.
Amalfitano S., Fazi S. 2008. Recovery and quantification of bacterial cells associated with streambed sediments. J. Microbiol. Meth. 75: 237-243. https://doi.org/10.1016/j.mimet.2008.06.004

Ambriz-Aviña V., Contreras-Garduño J.A., Pedraza-Reyes M. 2014. Applications of flow cytometry to characterize bacterial physiological responses. BioMed Res. Int. 14: 461941. https://doi.org/10.1155/2014/461941

Beniac D.R., Hiebert S.L., Siemens C.G., et al. 2015. A mobile biosafety microanalysis system for infectious agents. Sci. Rep. 5: 9505.

https://doi.org/10.1038/srep09505

Berney M., Hammes F., Bosshard F., et al. 2007. Assessment and interpretation of bacterial viability by using the LIVE/DEAD BacLight kit in combination with flow cytometry. Appl Environ Microbiol 73: 3283-3290. https://doi.org/10.1128/AEM.02750-06

Boulos L., Prévost M., Barbeau B., et al. 1999. LIVE/DEAD BacLightE: application of a new rapid staining method for direct enumeration of viable and total bacteria in drinking water. $J$. Microbiol. Methods 37: 77-86. https://doi.org/10.1016/S0167-7012(99)00048-2

Bouvier T., Troussellier M., Anzil A., et al. 2011. Using light scatter signal to estimate bacterial Bbiovolume by flow cytometry. Cytometry 44: 188-194. https://doi.org/10.1002/1097-0320(20010701)44:3<188::AIDCYTO1111>3.0.CO:2-C

Bunse C., Pinhassi J. 2017. Marine bacterioplankton seasonal succession dynamics. Trends Microbiol 25: 494-505. https://doi.org/10.1016/j.tim.2016.12.013

Combs C.A. 2010. Fluorescence microscopy: a concise guide to current imaging methods. Curr. Protoc. Neurosci. 2: Unit2.1. https://doi.org/10.1002/0471142301.ns0201s50

Cos P., Tote K., Horemans T., et al. 2010. Biofilms: an extra hurdle for effective antimicrobial therapy. Curr Pharm Des 16: 2279-2295. https://doi.org/10.2174/138161210791792868

Crawford G.N.C, Barer R. 1951. The Action of Formaldehyde on Living Cells as Studied by Phase-contrast Microscopy. Q. J. Microsc. Sci., 92(part 4): 403-52 https://doi.org/10.1242/jcs.s3-92.20.403

Dang H., Lovell C.R. 2002. Numerical dominance and phylotype diversity of marine Rhodobacter species during early colonization of submerged surfaces in coastal marine waters as determined by $16 \mathrm{~S}$ ribosomal DNA sequence analysis and fluorescence in situ hybridization. Appl. Environ. Microbiol. 68: 496-504. https://doi.org/10.1128/AEM.68.2.496-504.2002

Davey H.M., Kell D.B. 1996. Flow cytometry and cell sorting of heterogeneous microbial populations: the importance of single cell analyses. Microbiol. Rev. 60: 641-696. https://doi.org/10.1128/mr.60.4.641-696.1996

Davey H.M., Kell D.B. 1997. Fluorescent brighteners: novel stains for the flow cytometric analysis of microorganisms. Cytometry 28: 311-315.

https://doi.org/10.1002/(SICI)1097-0320(19970801) 28:4<311::AID-CYTO6>3.0.CO;2-E

Falcioni T., Papa S., Gasol J.M. 2008. Evaluating the flow-cytometric nucleic acid double-staining protocol in realistic situations of planktonic bacterial death. Appl. Environ. Microbiol. 74: 1767-1779. https://doi.org/10.1128/AEM.01668-07

Felip M., Andreatta S., Sommaruga R., et al. 2007. Suitability of flow cytometry for estimating bacterial biovolume in natural plankton samples: comparison with microscopy data. Eng. Fail. Anal. 73: 4508-4514. https://doi.org/10.1128/AEM.00733-07

Fischer E.R., Hansen B.T., Nair V., et al. 2012. Scanning electron microscopy. Curr. Protoc. Microbiol. 2B: 2. https://doi.org/10.1002/9780471729259.mc02b02s25

Flemming H-C., Wingender J. 2010. The biofilm matrix. Nat. Rev. 8: 623-633. https://doi.org/10.1038/nrmicro2415

Franklin R.B., Campbell A.H., Higgins C.B., et al. 2011. Enumerating bacterial cells on bioadhesive coated slides. J. Microbiol. Methods 87: 154-160. https://doi.org/10.1016/j.mimet.2011.08.013

Freitas V. da R., Sand S.T., Simonetti A.B. 2010. Formação in vitro de biofilme por Pseudomonas aeruginosa e Staphylococcus aureus na superfície de canetas odontológicas de alta rotação. Revista de Odontologia da UNESP 39: 193-200. 
Gant V.A., Warnes G., Phillips I., et al. 1993. The application of flow cytometry to the study of bacterial responses to antibiotics. J. Med. Microbiol. 39: 147-154. https://doi.org/10.1099/00222615-39-2-147

Garren M., Azam F. 2010. New method for counting bacteria associated with coral mucus. Appl. Environ. Microbiol. 76: 6128-6133. https://doi.org/10.1128/AEM.01100-10

Gasol J.M., Giorgio P.A. del. 2000. Using flow cytometry for counting natural planktonic bacteria and understanding the structure of planktonic bacterial communities. Sci. Mar. 64: 197-224. https://doi.org/10.3989/scimar.2000.64n2197

Golladay S.W., Sinsabaugh R.L. 1991. Biofilm development on leaf and wood surfaces in a boreal river. Freshwater Biol. 25: $437-450$ https://doi.org/10.1111/j.1365-2427.1991.tb01387.

Harrison J.J., Ceri H., Yerly J., et al. 2006. The use of microscopy and three-dimensional visualization to evaluate the structure of microbial biofilms cultivated in the Calgary Biofilm Device. Biol. Proced. 8: 194-215. https://doi.org/10.1251/bpo127

Hobbie J.E., Daley R., Jasper S. 1977. Use of Nuclepore filters for counting bacteria by fluorescence microscopy. Appl. Environ. Microbiol. 33: 1225-1228. https://doi.org/10.1128/aem.33.5.1225-1228.1977

Jin Y., Zhang T., Samaranayake Y.H., et al. 2005. The use of new probes and stains for improved assessment of cell viability and extracellular polymeric substances in Candida albicans biofilms. Mycopathologia 159: 353-360. https://doi.org/10.1007/s11046-004-6987-7

Jochem F.J. 2001. Morphology and DNA content of bacterioplankton in the western Gulf of Mexico: Analysis by epifluorescence microscopy and flow cytometry. Aquat. Microb. Ecol. 25: 179-194 https://doi.org/10.3354/ame025179

Kepner R.L.Jr., Pratt J.R. 1994. Use of fluorochromes for direct enumeration of total bacteria in environmental samples: past and present. Microbiol. Mol. Biol. Rev. 58: 603-615. https://doi.org/10.1128/mr.58.4.603-615.1994

Kerstens M., Boulet G., Van Kerckhoven M., et al. 2015. A flow cytometric approach to quantify biofilms. Folia Microbiol. 60: $335-342$ https://doi.org/10.1007/s12223-015-0400-4

Kim S.K., Lee J.H. 2016. Biofilm dispersion in Pseudomonas aeruginosa. J. Microbiol. 54: 71-85. https://doi.org/10.1007/s12275-016-5528-7

Lopes L.F.P., Agostini V.O., Guimarães S.S, et al. 2018. Evaluation of the effect of antimicrobials in marine cultures, using the copepod Acartia tonsa as a bioindicator. Chem. Ecol. 34: 747-761. https://doi.org/10.1080/02757540.2018.1482886

McKenzie A.T. 2019. Glutaraldehyde: A review of its fixative effects on nucleic acids, proteins, lipids, and carbohydrates. https://doi.org/10.31219/osf.io/8zd4e

Mohammed M.M.A., Nerland A.H., Al-Haroni M., et al. 2013. Characterization of extracellular polymeric matrix, and treatment of Fusobacterium nucleatum and Porphyromonas gingivalis biofilms with DNase I and proteinase K. J. Oral Microbiol. 5: 20015 https://doi.org/10.3402/jom.v5i0.20015

Monfort P., Baleux B. 1992. Comparison of flow cytometry and epifluorescence microscopy for counting bacteria in aquatic ecosystems. Cytometry 13: 188-192. https://doi.org/10.1002/cyto.990130213

Muthukrishnan T., Govender A., Dobretsov S., et al. 2017. Evaluating the reliability of counting bacteria using epifluorescence microscopy. J. Mar. Sci. Eng. 5: 4. https://doi.org/10.3390/jmse5010004

Nebe-von-Caron G., Stephens P.J., Badley R.A. 1999. Bacterial detection and differentiation by cytometry and fluorescent probes. Proc. Royal Soc. Lond. 34: 321-327.

Nebe-von-Caron G., Stephens P.J., Hewitt C.J., et al. 2000. Analysis of bacterial function by multi-colour fluorescence flow cytometry and single cell sorting. J. Microbiol. Methods 42: 97-114. https://doi.org/10.1016/S0167-7012(00)00181-0

Oliveira S.S., Wasielesky Jr W.F.B., Ballester E.L.C., et al. 2006. Caracterização da assembléia de bactérias nitrificantes pelo método "Fluorescent in situ Hybridization" (FISH) no bio- filme e água de larvicultura do Camarão-rosa Farfantepenaeus paulensis. Atlântica 28(1): 33-45.

Ophus M. 2014. Bacterial community dynamics in a biofilter exposed to a micropollutant. Norwegian University of Science and Technology. $123 \mathrm{pp}$

Oulahal N., Martial-Gros A., Bonneau M., et al. 2004. Combined effect of chelating agents and ultrasound on biofilm removal from stainless steel surfaces. Application to "Escherichia coli milk" and "Staphylococcus aureus milk" biofilms. Biofilms 1: 65-73. https://doi.org/10.1017/S1479050504001140

Parthasarathy R. 2018. Monitoring microbial communities using light sheet fluorescence microscopy. Curr. Opin. Microbiol. 43: 31-37.

https://doi.org/10.1016/j.mib.2017.11.008

Porter K.G., Feig Y.S. 1980. The use of DAPI for identifying and counting aquatic microflora. Limnol. Oceanogr. 25: 943-948. https://doi.org/10.4319/1o.1980.25.5.0943

Posch T., Loferer-Krößbacher M., Gao G., et al. 2001. Precision of bacterioplankton biomass determination: a comparison of two fluorescent dyes, and of allometric and linear volume-to-carbon conversion factors. Aquat. Microb. Ecol. 25: 55-63. https://doi.org/10.3354/ame025055

R Core Team. R. 2017. A language and environment for statistical computing. R Foundation for Statistical Computing, Vienna, Austria. URL https://www.R-project.org/. 2017.

Sailer M.F., van Nieuwenhuijzen E.J., Knol W. 2010. Forming of a functional biofilm on wood surfaces. Ecol Eng 36: 163167. https://doi.org/10.1016/j.ecoleng.2009.02.004

Sgier L., Freimann R., Zupanic A., et al. 2016. Flow cytometry combined with viSNE for the analysis of microbial biofilms and detection of microplastics. Nat. Commun. 7: 11587. https://doi.org/10.1038/ncomms11587

Shapiro H.M., Nebe-Von-Caron G. 2004. Multiparameter flow cytometry of bacteria. Methods Mol. Biol. 263: 33-44.

Shi L., Günther S., Hübschmann T., et al. 2007. Limits of propidium iodide as a cell viability indicator for environmental bacteria. Cytometry Part A 71A: 592-598. https://doi.org/10.1002/cyto.a.20402

Suzuki M.T. 1993. DAPI direct counting underestimates bacterial abundances and average cell size compared to AO direct counting. Limnol. Oceanogr. 38: 1566-1570 https://doi.org/10.4319/1o.1993.38.7.1566

Troussellier M., Courties C., Lebaron P., et al. 1999. Flow cytometric discrimination of bacterial populations in seawater based on SYTO 13 staining of nucleic acids. FEMS Microbiol. Ecol. 29: 319-330. https://doi.org/10.1111/j.1574-6941.1999.tb00623.x

Walberg M., Gaustad P., Steen H.B. 1996. Rapid flow cytometric assessment of mecillinam and ampicillin bacterial susceptibility. J. Antimicrob. Chemother 37: 1063-1075. https://doi.org/10.1093/jac/37.6.1063

Xu J., Bigelow T.A., Halverson L.J., et al. 2012. Mechanical destruction of Pseudomonas aeruginosa biofilms by ultrasound exposure. AIP Conf. Proc. 1481: 463-468. https://doi.org/10.1063/1.4757378

Yu M., Wu L., Huang T., et al. 2015. Rapid detection and enumeration of total bacteria in drinking water and tea beverages using a laboratory-built high-sensitivity flow cytometer. Anal Methods 7: 3072-3079. https://doi.org/10.1039/C4AY02919D

Zhang R., Neu T.R., Zhang Y., et al. 2015. Visualization and analysis of EPS glycoconjugates of the thermoacidophilic archaeon Sulfolobus metallicus. Appl. Microbiol. Biotechnol. 99: 7343-7356. https://doi.org/10.1007/s00253-015-6775-y

Zimmerman R., Meyer-Reil L-A. 1974. A new method for fluorescence staining of bacterial populations on membrane filters. Kiel Meeresforsch. 30: 24-27. 


\section{SUPPLEMENTARY MATERIAL}

The following supplementary material is available through the online version of this article and at the following link: http://scimar.icm.csic.es/scimar/supplm/ sm05117esm.pdf

Table S1. - Stain potential to dye compromised and non-compromised cell membranes, and detritus.

Table S2. - Fluorescence characteristics of the stains used to count and measure marine free-living and biofilm prokaryotes by flow cytometer (Tsuboi et al. 2000, Riccardi and Nicoletti 2006, Pharmingen BD 2020).

Table S3. - Free-living (ind $\mathrm{mL}^{-1}$ ) and biofilm (ind $\mathrm{cm}^{-2}$ ) prokaryote densities estimated by flow cytometer (unstained, AO, DAPI, PI and SYTO9) at 6 and 12 days of exposure.

Fig. S1. - Differences between bacteria/archaea intact and compromised cell membranes. Photo from scanning electron microscope $(10000 \times)$ showing marine prokaryote biofilm on plywood substrate.

Fig. S2. - One-way ANOVA results showing differences in prokaryotes cells recorded by the flow cytometer with stains compared with detritus/non-stained particles at 6 and 12 days of exposure. A, free-living prokaryotes at 6 days; B, free-living prokaryotes at 12 days; $\mathrm{C}$, biofilm prokaryotes at 6 days; D, biofilm prokaryotes at 12 days. Vertical lines denote confidence intervals (95\%) (standard error*1.96).
Lowercase letters indicate statistical similarities $(\mathrm{p}>0.05)$ or differences $(\mathrm{p}<0.05)$.

Fig. S3. - A, instrument configuration details of the filters and mirrors used on the BD FACSVerse ${ }^{\mathrm{TM}}$. B, histograms show the fluorescence profiles at the FL-3 channel (PE). The curves correspond to the cells unstained and stained with propidium iodide (PI) or acridine orange (AO). C, histograms show the fluorescence profiles at the FL-1 channel (FITC). The curves correspond to the cells unstained and stained with green fluorescent nucleic acid (SYTO9) or 4'-6-diamidino-2-phenylidole, dihydrochloride (DAPI). In both cases, the unstained cells were considered as background and the percentage of those above the background was considered as positive. The fluorochromes were added and analysed separately in each tube, excluding exclude the possibility of interference between them. D, FSC vs SSC dot plot of the bacteria population showing all the events that were considered in the analysis. The FSC vs SSC plot of the stained cells (AO, PI, DAPI, SYTO9) shows that these parameters were similar to those of the unstained sample.

Fig. S4. - Marine free-living and biofilm prokaryote populations at 6 and 12 days of exposure estimated by different methodologies: using a flow cytometer (FC) (BD FacsVerse ${ }^{\mathrm{TM}}$ ), where lighter colours are related to higher density cells, forward light scatter for size estimates (FSC-A), light side scatter for complexity estimates (SSC-A). A, using an epifluorescence microscope (EFM) stained with acridine orange; B, using a scanning electronic microscope (SEM) (C). 
SCientia Marina 85(3)

September 2021, S1-S6, Barcelona (Spain)

ISSN-L: 0214-8358

\section{Comparison of techniques for counting prokaryotes in marine planktonic and biofilm samples}

Vanessa Ochi Agostini, Letícia Terres Rodrigues, Alexandre José Macedo, Erik Muxagata

Supplementary material 
Table S1. - Stain potential to dye compromised and non-compromised cell membranes, and detritus.

\begin{tabular}{|c|c|c|c|c|}
\hline Dye & $\begin{array}{l}\text { Non-compromised } \\
\text { membrane }\end{array}$ & $\begin{array}{l}\text { Compromised } \\
\text { membrane }\end{array}$ & Detritus/debris & Reference \\
\hline Unstained & - & $\cdot$ & - & Davey and Kell 1997 \\
\hline $\mathrm{AO}$ & . & . & . & Harrison et al. 2006 \\
\hline DAPI & . & . & & Neu et al. 2002 \\
\hline SYTO9 & . & . & & Zhang et al. 2015 \\
\hline PI & & . & & Jin et al. 2005 \\
\hline
\end{tabular}

Table S2. - Fluorescence characteristics of the stains used to count and measure marine free-living and biofilm prokaryotes by flow cytometer (Tsuboi et al. 2000, Riccardi and Nicoletti 2006, Pharmingen BD 2020).

\begin{tabular}{lccc}
\hline Dye & Excitation & Emission & Laser line \\
\hline DAPI & $360 \mathrm{~nm}$ & $460 \mathrm{~nm}$ & Colour \\
PI & $530 \mathrm{~nm}$ & $620 \mathrm{~nm}$ & blue \\
AO & $420-460 \mathrm{~nm}$ & $630-650 \mathrm{~nm}$ & $488 \mathrm{~nm}$ \\
SYTO9 & $485 \mathrm{~nm}$ & $498 \mathrm{~nm}$ & $473-532 \mathrm{~nm}$ \\
\hline
\end{tabular}

Table S3. - Free-living (ind $\mathrm{mL}^{-1}$ ) and biofilm (ind $\mathrm{cm}^{-2}$ ) prokaryote densities estimated by flow cytometer (unstained, AO, DAPI, PI and SYTO9) at 6 and 12 days of exposure.

\begin{tabular}{|c|c|c|c|c|c|}
\hline \multirow{2}{*}{ Treatment } & \multirow{2}{*}{ Replicate } & \multicolumn{2}{|c|}{ Biofilm cells $\mathrm{cm}^{-2}$} & \multicolumn{2}{|c|}{ Free-living cells $\mathrm{mL}^{-1}$} \\
\hline & & 6 days & 12 days & 6 days & 12 days \\
\hline Unstained & $\mathrm{R} 1$ & $2.17 \mathrm{E}+06$ & $4.53 \mathrm{E}+06$ & $5.71 \mathrm{E}+05$ & $3.86 \mathrm{E}+06$ \\
\hline Unstained & $\mathrm{R} 2$ & $2.00 \mathrm{E}+06$ & $4.57 \mathrm{E}+06$ & $4.77 \mathrm{E}+05$ & $3.37 \mathrm{E}+05$ \\
\hline Unstained & $\mathrm{R} 3$ & $2.05 \mathrm{E}+06$ & $4.45 \mathrm{E}+06$ & $1.52 \mathrm{E}+06$ & $2.31 \mathrm{E}+05$ \\
\hline Unstained & $\mathrm{R} 4$ & $2.00 \mathrm{E}+06$ & $4.01 \mathrm{E}+06$ & $4.90 \mathrm{E}+05$ & $1.20 \mathrm{E}+06$ \\
\hline Unstained & $\mathrm{R} 5$ & $1.99 \mathrm{E}+06$ & $4.47 \mathrm{E}+06$ & $3.47 \mathrm{E}+06$ & $2.46 \mathrm{E}+05$ \\
\hline Unstained & R6 & $2.01 \mathrm{E}+06$ & $4.62 \mathrm{E}+06$ & $4.85 \mathrm{E}+05$ & $2.23 \mathrm{E}+05$ \\
\hline Unstained & R7 & $1.99 \mathrm{E}+06$ & $4.36 \mathrm{E}+06$ & $5.00 \mathrm{E}+05$ & $1.25 \mathrm{E}+06$ \\
\hline Unstained & $\mathrm{R} 8$ & $1.95 \mathrm{E}+06$ & $4.55 \mathrm{E}+06$ & $5.49 \mathrm{E}+05$ & $3.25 \mathrm{E}+05$ \\
\hline Unstained & R9 & $2.00 \mathrm{E}+06$ & $4.55 \mathrm{E}+06$ & $2.52 \mathrm{E}+06$ & $3.37 \mathrm{E}+05$ \\
\hline Unstained & R10 & $2.03 \mathrm{E}+06$ & $4.69 \mathrm{E}+06$ & $5.02 \mathrm{E}+05$ & $3.12 \mathrm{E}+05$ \\
\hline $\mathrm{AO}$ & $\mathrm{R} 1$ & $2.12 \mathrm{E}+06$ & $4.49 \mathrm{E}+06$ & $5.61 \mathrm{E}+05$ & $3.77 \mathrm{E}+06$ \\
\hline $\mathrm{AO}$ & $\mathrm{R} 2$ & $1.97 \mathrm{E}+06$ & $4.50 \mathrm{E}+06$ & $4.69 \mathrm{E}+05$ & $3.27 \mathrm{E}+05$ \\
\hline $\mathrm{AO}$ & R3 & $2.02 \mathrm{E}+06$ & $4.28 \mathrm{E}+06$ & $1.50 \mathrm{E}+06$ & $2.29 \mathrm{E}+05$ \\
\hline $\mathrm{AO}$ & R4 & $1.99 \mathrm{E}+06$ & $3.98 \mathrm{E}+06$ & $4.84 \mathrm{E}+05$ & $1.19 \mathrm{E}+06$ \\
\hline $\mathrm{AO}$ & R5 & $1.96 \mathrm{E}+06$ & $4.45 \mathrm{E}+06$ & $3.41 \mathrm{E}+06$ & $2.43 \mathrm{E}+05$ \\
\hline $\mathrm{AO}$ & R6 & $2.01 \mathrm{E}+06$ & $4.56 \mathrm{E}+06$ & $4.78 \mathrm{E}+05$ & $2.22 \mathrm{E}+05$ \\
\hline $\mathrm{AO}$ & R7 & $1.98 \mathrm{E}+06$ & $4.35 \mathrm{E}+06$ & $4.95 \mathrm{E}+05$ & $1.24 \mathrm{E}+06$ \\
\hline $\mathrm{AO}$ & R8 & $1.93 \mathrm{E}+06$ & $4.52 \mathrm{E}+06$ & $5.41 \mathrm{E}+05$ & $3.22 \mathrm{E}+05$ \\
\hline $\mathrm{AO}$ & R9 & $1.99 \mathrm{E}+06$ & $4.52 \mathrm{E}+06$ & $2.49 \mathrm{E}+06$ & $3.34 \mathrm{E}+05$ \\
\hline $\mathrm{AO}$ & R10 & $2.02 \mathrm{E}+06$ & $4.67 \mathrm{E}+06$ & $4.94 \mathrm{E}+05$ & $3.07 \mathrm{E}+05$ \\
\hline DAPI & $\mathrm{R} 1$ & $2.17 \mathrm{E}+06$ & $4.45 \mathrm{E}+06$ & $5.26 \mathrm{E}+05$ & $3.57 \mathrm{E}+06$ \\
\hline DAPI & $\mathrm{R} 2$ & $2.00 \mathrm{E}+06$ & $4.54 \mathrm{E}+06$ & $4.32 \mathrm{E}+05$ & $3.19 \mathrm{E}+05$ \\
\hline DAPI & R3 & $2.04 \mathrm{E}+06$ & $4.40 \mathrm{E}+06$ & $1.43 \mathrm{E}+06$ & $2.23 \mathrm{E}+05$ \\
\hline DAPI & R4 & $1.98 \mathrm{E}+06$ & $3.99 \mathrm{E}+06$ & $4.51 \mathrm{E}+05$ & $1.17 \mathrm{E}+06$ \\
\hline DAPI & $\mathrm{R} 5$ & $1.96 \mathrm{E}+06$ & $4.43 \mathrm{E}+06$ & $3.14 \mathrm{E}+06$ & $2.38 \mathrm{E}+05$ \\
\hline DAPI & R6 & $1.97 \mathrm{E}+06$ & $4.54 \mathrm{E}+06$ & $4.36 \mathrm{E}+05$ & $2.14 \mathrm{E}+05$ \\
\hline DAPI & R7 & $1.91 \mathrm{E}+06$ & $4.34 \mathrm{E}+06$ & $4.50 \mathrm{E}+05$ & $1.22 \mathrm{E}+06$ \\
\hline DAPI & R8 & $1.83 \mathrm{E}+06$ & $4.53 \mathrm{E}+06$ & $5.09 \mathrm{E}+05$ & $3.17 \mathrm{E}+05$ \\
\hline DAPI & R9 & $1.87 \mathrm{E}+06$ & $4.51 \mathrm{E}+06$ & $2.35 \mathrm{E}+06$ & $3.19 \mathrm{E}+05$ \\
\hline DAPI & $\mathrm{R} 10$ & $1.84 \mathrm{E}+06$ & $4.61 \mathrm{E}+06$ & $4.69 \mathrm{E}+05$ & $3.00 \mathrm{E}+05$ \\
\hline PI & $\mathrm{R} 1$ & $2.04 \mathrm{E}+06$ & $4.52 \mathrm{E}+06$ & $5.07 \mathrm{E}+05$ & $3.56 \mathrm{E}+06$ \\
\hline PI & $\mathrm{R} 2$ & $1.85 \mathrm{E}+06$ & $4.53 \mathrm{E}+06$ & $4.15 \mathrm{E}+05$ & $2.95 \mathrm{E}+05$ \\
\hline PI & R3 & $1.93 \mathrm{E}+06$ & $4.36 \mathrm{E}+06$ & $1.37 \mathrm{E}+06$ & $2.10 \mathrm{E}+05$ \\
\hline PI & R4 & $1.81 \mathrm{E}+06$ & $3.80 \mathrm{E}+06$ & $4.31 \mathrm{E}+05$ & $1.17 \mathrm{E}+06$ \\
\hline PI & R5 & $1.89 \mathrm{E}+06$ & $3.99 \mathrm{E}+06$ & $2.99 \mathrm{E}+06$ & $2.29 \mathrm{E}+05$ \\
\hline PI & R6 & $1.89 \mathrm{E}+06$ & $4.08 \mathrm{E}+06$ & $4.18 \mathrm{E}+05$ & $2.13 \mathrm{E}+05$ \\
\hline PI & R7 & $1.86 \mathrm{E}+06$ & $3.57 \mathrm{E}+06$ & $4.34 \mathrm{E}+05$ & $1.15 \mathrm{E}+06$ \\
\hline PI & $\mathrm{R} 8$ & $1.81 \mathrm{E}+06$ & $3.55 \mathrm{E}+06$ & $4.91 \mathrm{E}+05$ & $3.17 \mathrm{E}+05$ \\
\hline PI & R9 & $1.84 \mathrm{E}+06$ & $2.98 \mathrm{E}+06$ & $2.28 \mathrm{E}+06$ & $3.04 \mathrm{E}+05$ \\
\hline PI & R10 & $1.92 \mathrm{E}+06$ & $4.64 \mathrm{E}+06$ & $4.54 \mathrm{E}+05$ & $2.64 \mathrm{E}+05$ \\
\hline SYTO 9 & R1 & $2.16 \mathrm{E}+06$ & $4.52 \mathrm{E}+06$ & $5.00 \mathrm{E}+05$ & $3.50 \mathrm{E}+06$ \\
\hline SYTO 9 & $\mathrm{R} 2$ & $2.00 \mathrm{E}+06$ & $4.54 \mathrm{E}+06$ & $4.05 \mathrm{E}+05$ & $2.88 \mathrm{E}+05$ \\
\hline SYTO 9 & $\mathrm{R} 3$ & $2.05 \mathrm{E}+06$ & $4.44 \mathrm{E}+06$ & $1.36 \mathrm{E}+06$ & $2.01 \mathrm{E}+05$ \\
\hline
\end{tabular}




\begin{tabular}{cccccc}
\hline \multirow{2}{*}{ Treatment } & \multirow{2}{*}{ Replicate } & \multicolumn{2}{c}{ Biofilm cells cm } & \multicolumn{2}{c}{ Free-living cells $\mathrm{mL}^{-1}$} \\
\cline { 3 - 5 } & & 6 days & 12 days & 6 days & 12 days \\
\hline SYTO 9 & R4 & $1.99 \mathrm{E}+06$ & $4.00 \mathrm{E}+06$ & $4.27 \mathrm{E}+05$ & $1.14 \mathrm{E}+06$ \\
SYTO 9 & R5 & $1.98 \mathrm{E}+06$ & $4.42 \mathrm{E}+06$ & $2.97 \mathrm{E}+06$ & $2.22 \mathrm{E}+05$ \\
SYTO 9 & R6 & $2.01 \mathrm{E}+06$ & $4.57 \mathrm{E}+06$ & $4.04 \mathrm{E}+05$ & $1.13 \mathrm{E}+05$ \\
SYTO 9 & R7 & $1.98 \mathrm{E}+06$ & $4.32 \mathrm{E}+06$ & $4.31 \mathrm{E}+05$ & $3.08 \mathrm{E}+05$ \\
SYTO 9 & R8 & $1.94 \mathrm{E}+06$ & $4.52 \mathrm{E}+06$ & $4.87 \mathrm{E}+05$ & $2.99 \mathrm{E}+05$ \\
SYTO 9 & R9 & $2.00 \mathrm{E}+06$ & $4.53 \mathrm{E}+06$ & $2.25 \mathrm{E}+06$ & $2.60 \mathrm{E}+05$ \\
SYTO 9 & R10 & $1.92 \mathrm{E}+06$ & $4.68 \mathrm{E}+06$ & $4.47 \mathrm{E}+05$ & \\
\hline
\end{tabular}

Fig. S1. - Differences between bacteria/archaea intact and compromised cell membranes. Photo from scanning electron microscope $(10000 \times)$ showing marine prokaryote biofilm on plywood substrate.

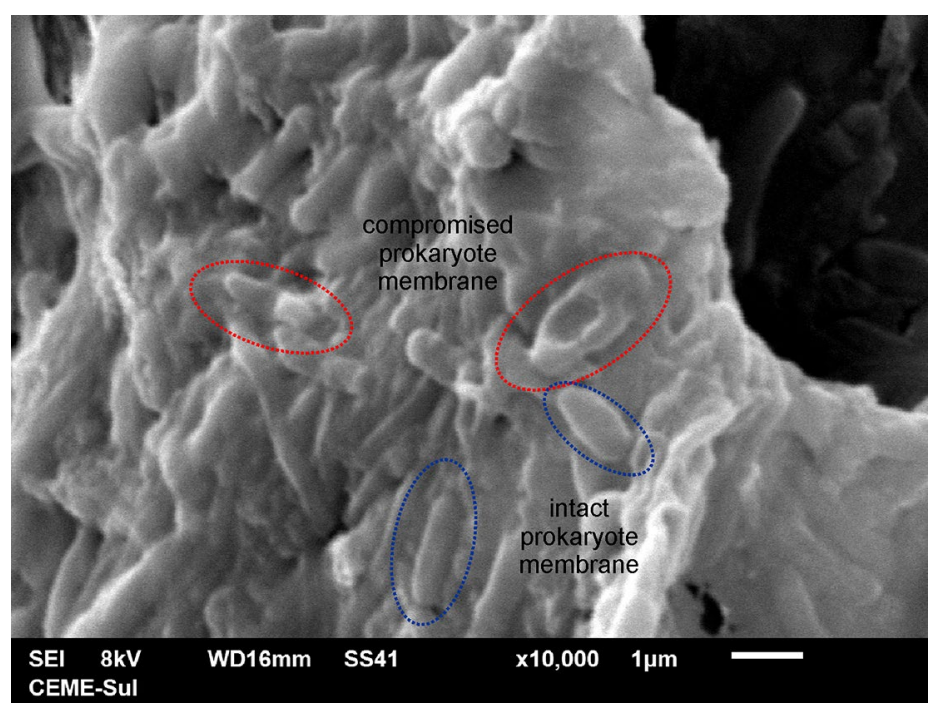

Fig. S2. - One-way ANOVA results showing differences in prokaryotes cells recorded by the flow cytometer with stains compared with detritus/non-stained particles at 6 and 12 days of exposure. A, free-living prokaryotes at 6 days; B, free-living prokaryotes at 12 days; C, biofilm prokaryotes at 6 days; D, biofilm prokaryotes at 12 days. Vertical lines denote confidence intervals (95\%) (standard error*1.96). Lowercase letters indicate statistical similarities $(p>0.05)$ or differences $(p<0.05)$.

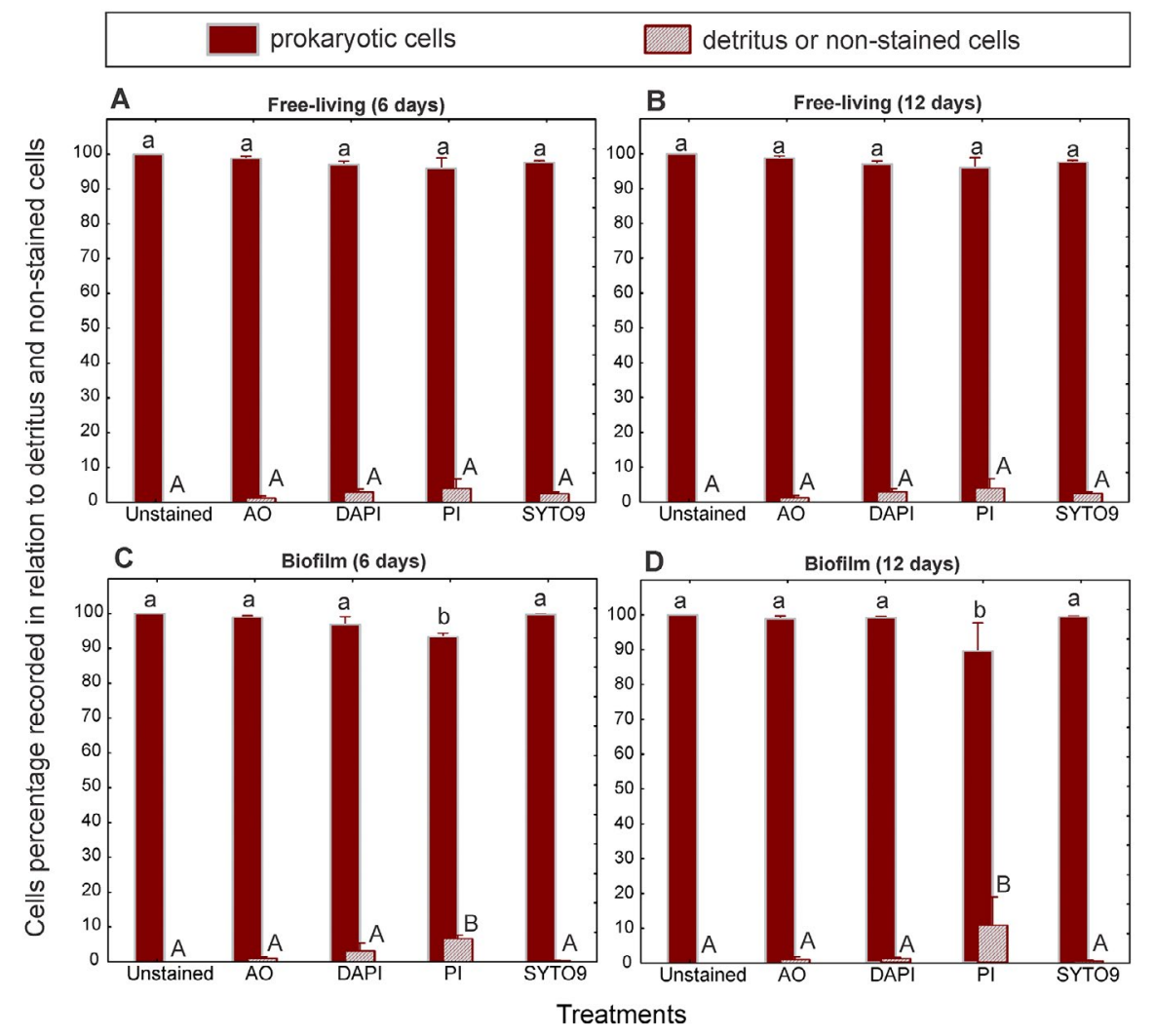


Fig. S3. - A, instrument configuration details of the filters and mirrors used on the BD FACSVerse ${ }^{\mathrm{TM}}$. B, histograms show the fluorescence profiles at the FL-3 channel (PE). The curves correspond to the cells unstained and stained with propidium iodide (PI) or acridine orange (AO). C, histograms show the fluorescence profiles at the FL-1 channel (FITC). The curves correspond to the cells unstained and stained with green fluorescent nucleic acid (SYTO9) or 4'-6-diamidino-2-phenylidole, dihydrochloride (DAPI). In both cases, the unstained cells were considered as background and the percentage of those above the background was considered as positive. The fluorochromes were added and analysed separately in each tube, excluding exclude the possibility of interference between them. D, FSC vs SSC dot plot of the bacteria population showing all the events that were considered in the analysis. The FSC vs SSC plot of the stained cells (AO, PI, DAPI, SYTO9) shows that these parameters were similar to those of the unstained sample.
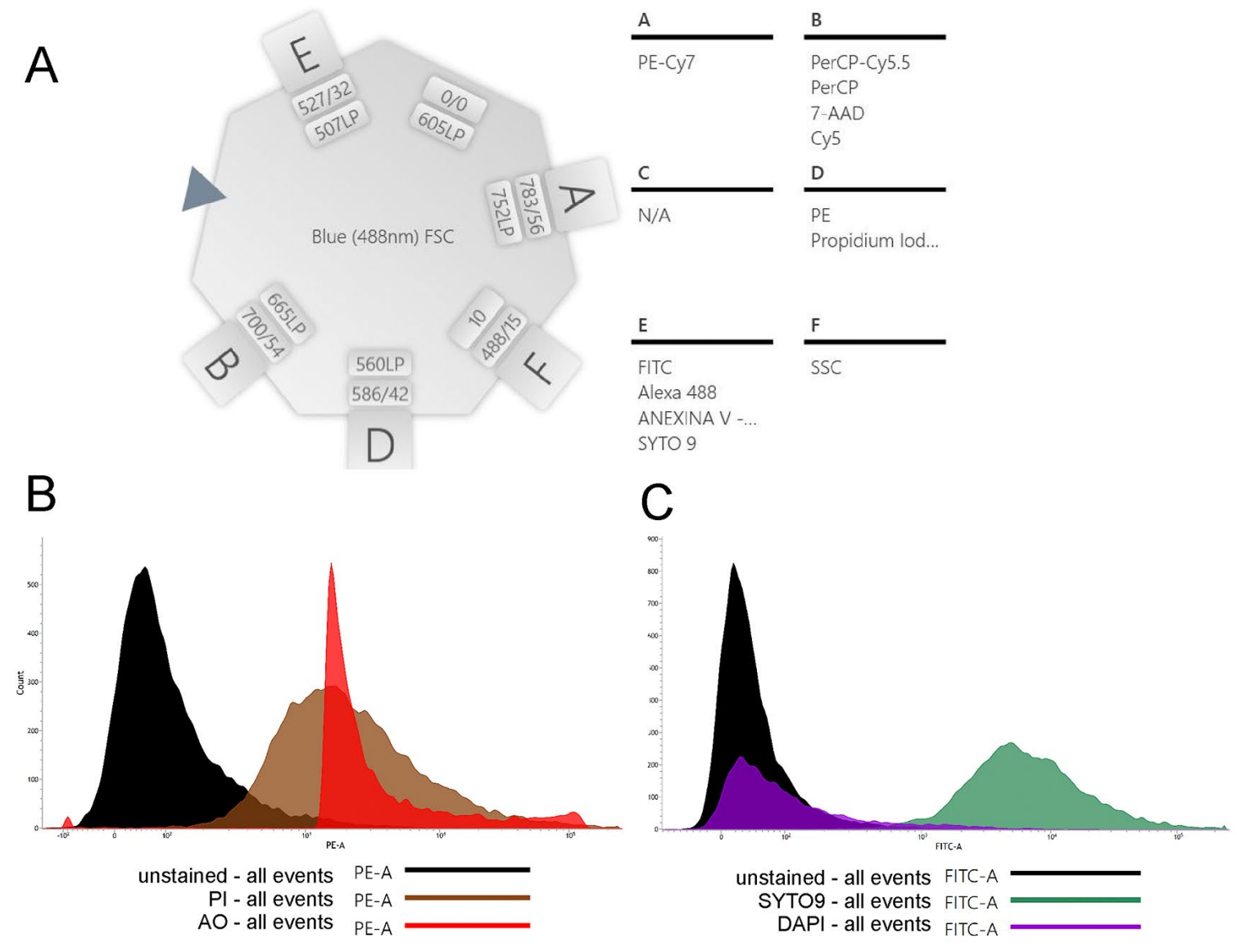

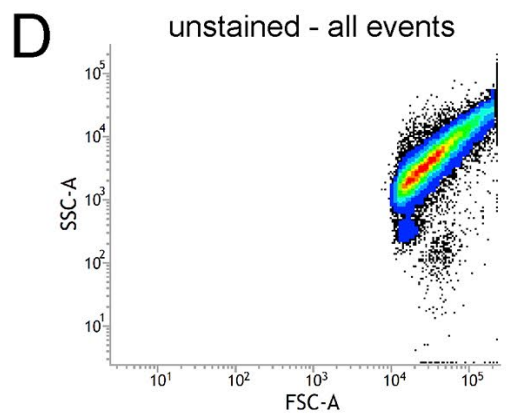

DAPI - all events

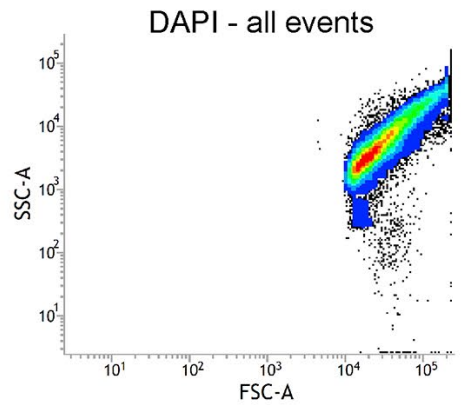

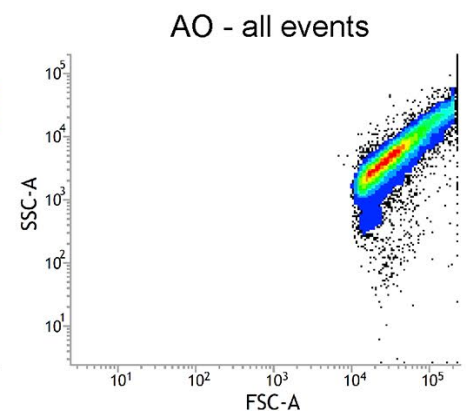

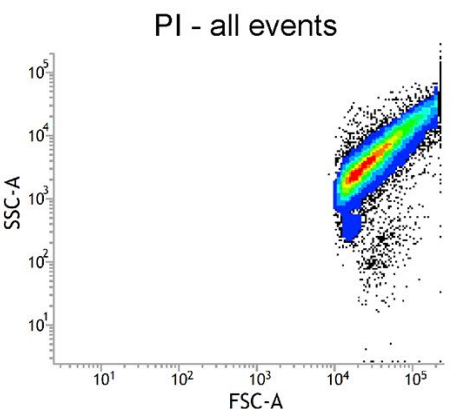

SYTO9 - all events

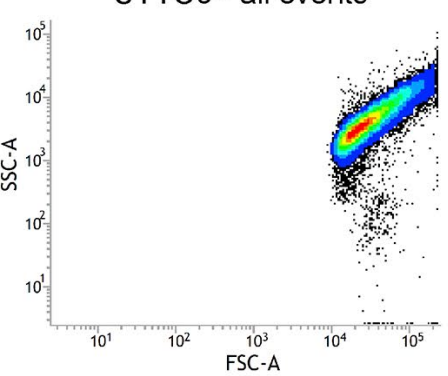


Fig. S4. - Marine free-living and biofilm prokaryote populations at 6 and 12 days of exposure estimated by different methodologies: using a flow cytometer $(\mathrm{FC})\left(\mathrm{BD}\right.$ FacsVerse $\left.{ }^{\mathrm{TM}}\right)$, where lighter colours are related to higher density cells, forward light scatter for size estimates (FSC-A), light side scatter for complexity estimates (SSC-A). A, using an epifluorescence microscope (EFM) stained with acridine orange; B, using a scanning electronic microscope (SEM) (C).

A
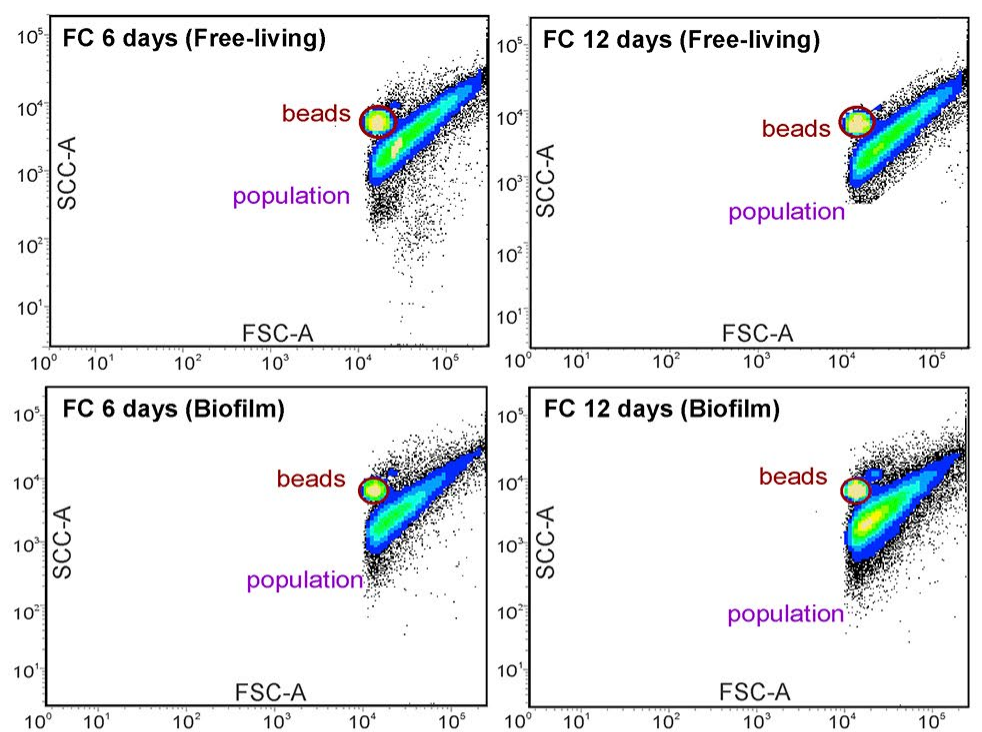

B

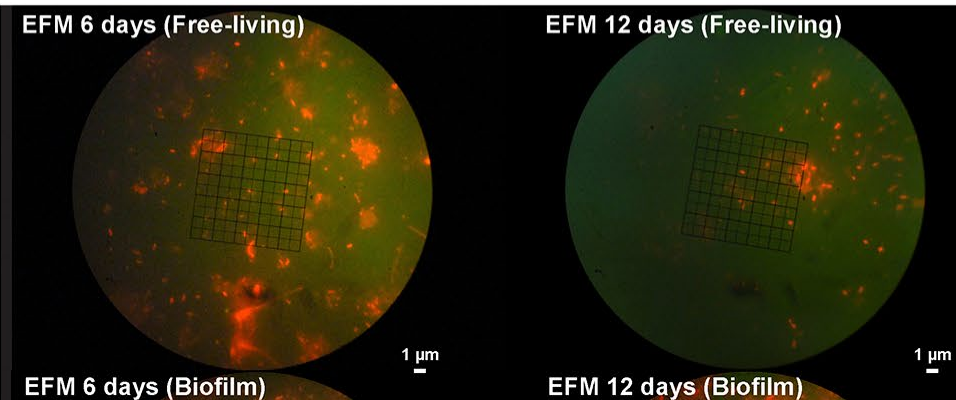

EFM 12 days (Biofilm)

\section{C}

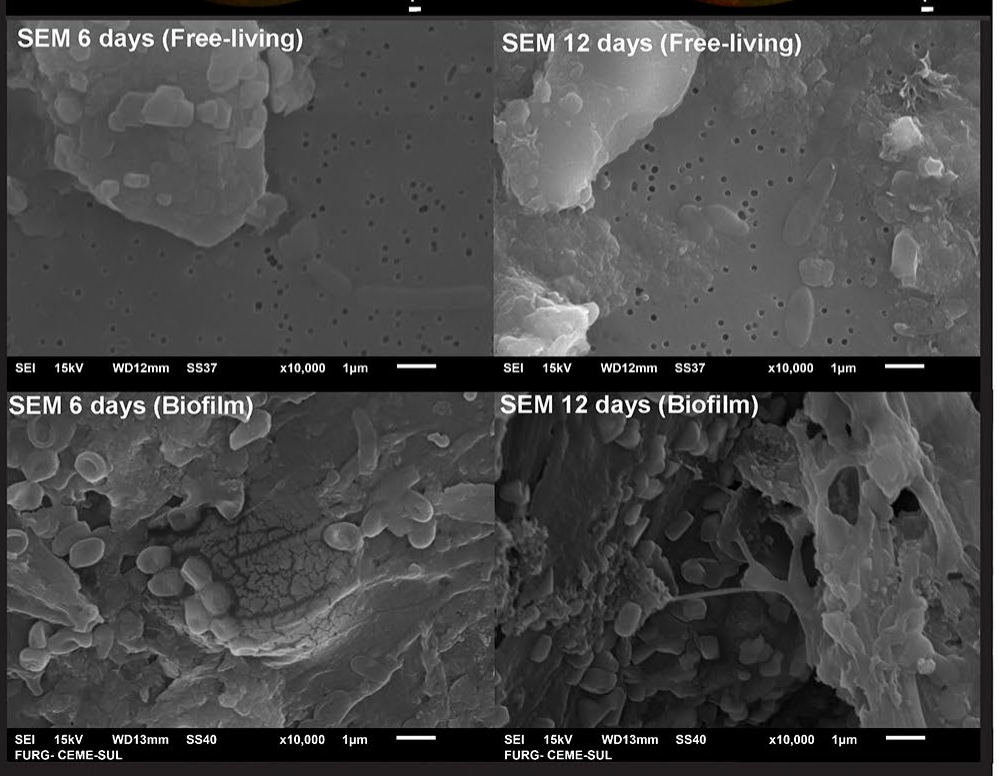




\section{REFERENCES}

Davey H.M., Kell D.B. 1997. Fluorescent brighteners: novel stains for the flow cytometric analysis of microorganisms. Cytometry 28: 311-315.

Harrison J.J., Ceri H., Yerly J., et al. 2006. The use of microscopy and three-dimensional visualization to evaluate the structure of microbial biofilms cultivated in the Calgary Biofilm Device. Biol. Proced. 8(1): 194-215.

Jin Y., Zhang T., Samaranayake Y.H., et al. 2005. The use of new probes and stains for improved assessment of cell viability and extracellular polymeric substances in Candida albicans biofilms. Mycopathologia 159: 353-360.

Neu T.R., Kuhlicke U., Lawrence J.R. 2002. Assessment of fluorochromes for two-photon laser scanning microscopy of biofilms. Appl. Environ. Microbiol. 68(2): 901-909.

Oliveira S.S., Wasielesky Jr W.F.B., Ballester E.L.C., et al. 2006. Caracterização da assembléia de bactérias nitrificantes pelo método "Fluorescent in situ Hybridization" (FISH) no bio- filme e água de larvicultura do Camarão-rosa Farfantepenaeus paulensis. Atlântica 28(1): 33-45.

Tsuboi T., Zhao C., Terakawa S., et al. 2006. A Simultaneous evanescent wave imaging of insulin vesicle membrane and cargo during a single exocytotic event. Current Biology 10: $1307-1310$

BD Pharmingen. 2020. DAPI Solution. Accessed on 20 July 2020. Available at www.bdbiosciences.com/en-eu/search-results? searchKey $=564907$

Riccardi C., Nicoletti I. 2006. Analysis of apoptosis by propidium iodide staining and flow cytometry. Nature Protocols 1(3): 1458-1461.

Zhang R., Neu T.R., Zhang Y., et al. 2015. Visualization and analysis of EPS glycoconjugates of the thermoacidophilic archaeon Sulfolobus metallicus. Appl. Microbiol. Biotechnol. 99: 7343-7356. 